Professor Michael Bromley is head of the School of Journalism and Communication at the University of Queensland.

\section{A geo-political review of education}

\section{for journalists}

Media Education in Asia, edited by Chi-Kim Cheung. Heidelberg: Springer, 2009, 239 pp. ISBN 9781402095283.

TT IS almost axiomatic in university journalism programmes everywhere that students embark on their tertiary studies unprepared by their schooling at secondary level. Learning in school is viewed, at one level, as being either inadequate (even non-existent) or muddle-headed, and, at another level, as deliberately subversive of the journalism project. As journalism programmes have grown in popularity, this tension, which could once be dismissed as marginal, has assumed far greater importance as illustrative of the contemporary dilemma of negotiating a place for education in the facilitation of media literacy.
Chi-Kim Cheung

Editor

\section{Media Education in Asia}

Springer

Briefly, as learning occurs formally and informally in an array of settings, each component strives for pre-eminence. Formal learning in educational institutions is paralleled by a system based on the workplace. A third element (the creative) both straddles these arrangements and lies outside them. As Cheng points out in this volume (p. 14), de-industrialisation and digitisation have collapsed many, if not all, of these distinctions.

The production and reception of contemporary media texts links education, creativity and citizenship (school, work and private life). Nevertheless, the continual assault on 
programmes as simultaneously 'too theoretical' and 'too practical' is testimony of the many stand-offs which still characterise the relationships.

One dimension most commonly missing from the equation, as the editor of this collection of essays, Cheung, reminds us (p. 7), is the students' own encountered knowledge. It is clear that in the 21 st century students arrive at either school or university with considerable prior experiences of media, and capacity to produce media texts. However, they are not always the understandings and practices which teachers appreciate. The underlying starting-point is most routinely that 'young people are deficient in media', Dezuanni argues in a chapter on Australia (p. 47).

His point is that educators should back off and instead aim 'to harness the power young people already have in the cultural process to show how it can be further utilised for active citizenship'. Here, then, we perhaps reach the nub of why university journalism educators believe students are inadequately prepared for higher education programs in the field.

Admittedly, there is a longstanding tendency in schools to treat all aspects of the media as 'a bad thing', an approach which appears to be surprisingly resilient throughout Asia (a depressing list of assumed negatives is provided by Aram and Paul at the beginning of their chapter on India [p.121]). Teaching training is chiefly poor even where media education is thriving, as in New Zealand, and, Lealand suggests, is indicative of a wider lack of infrastructure (p 55). Formal and informal learning are rarely linked; for example, Jeong points out that in South Korea, there is no formal education but a strong informal sector (p. 63).

Most of all, though, there is the problematic of practice. Much contemporary media education remains fixed on deconstruction rather than creation and the use of media as a means of creative expression, and effective use of and participation in available media channels' (UNESCO Declaration on Media Education, 1982). Journalism in particular recoils from any 'creative, imaginative and aesthetic activity' (Oxford \& Cambridge RSA, 2005, p. 15).

This is perverse, Cheng argues (p. 14), in a de-industrialised culture. It might be conjectured that, as journalism entered the academy, it became more bureaucratic, adopting the process of asking standard questions to elicit standard answers, whereas, as Cheng points out (p. 15), media production is un-amenable to standardisation. Journalism has exhibited an accompanying failure to 
recognise that today multimedia lie at the core of 'the basic knowledge and skills that ... enable effective communication'.

Yet media production of all types satisfies many educational needs, Buckingham and Domaille argue (p. 24), because it "necessarily entails a more "active", "student-centred", "participatory" pedagogy'. In these ways it also draws on essential dimensions of the apprenticeship tradition which has been so characteristic of journalism. Nevertheless, what students do is often devaluated as just 'student journalism'.

The example of the Young Journalists Group in Vietnam where journalism is engaged with a state transiting from Communist authoritarianism, as explained by Asthana (pp. 109-114), is instructive in that, after initial struggles to be accepted by the conventional media, the junior reporters' self-expression is now being embraced.

In canvassing a variety of practices and possibilities, this book traverses old ground, which we ignore to our disadvantage, and introduces new contexts which illuminate the condition of media education from the perspective of one of the most important and contested geo-political locales. The chapters mainly scope by country (Australia, China, Hong
Kong, India, Japan, Kyrgyzstan, New Zealand, Singapore, South Korea, Taiwan, Thailand and Vietnam), providing a descriptive base for analysis.

Insofar as the collection is a conscious attempt to de-Westernise media education, it is both a success and a failure. Cheung concludes ( $p$. 217) that the commonalities fostered by globalisation generally outweigh the specificities of cultural context. At the same time, globalisation is inherently cross-cultural, and Asia's forceful presence has to be taken into account. The conceptualisation of modern mass media may be Western in origin, but many of the practices of contemporary media are not.

\section{References}

Oxford Cambridge and RSA Examinations (2005). OCRGCSE Media studies (2nd ed.). Cambridge: OCR.

UNESCO (1982). UNESCO declaration on media education issued by the representatives of 19 nations at UNESCO's 1982 International Symposium on Media Education. Grunwald, German: UNESCO. 